\title{
Arginase Activity Determination A Marker of Large Bowel Mucosa Proliferation
}

\author{
Petr Kocna, Přemysl Frič, Miroslav Zavoral and Tomáš Pelech \\ Laboratory of Gastroenterology and Department of Internal Medicine, 1st Medical Faculty, Charles University, \\ Prague, Czech Republic
}

Summary: Arginase activity of the intestinal mucosa was tested as a proliferative marker in the adenoma-carcinoma sequence. The enzyme activity was determined by an end-point colorimetric method with $L$-arginine as substrate. Arginase activity was evaluated in 430 biopsy samples of large bowel mucosa, polyps and cancer tissue. The activities (U/g protein, mean $\pm \mathrm{SE} ; \mathrm{n}$ ) were: normal mucosa $83.2 \pm 7.3 ; 25$, adenomas $199.4 \pm 19.1 ; 40$, carcinomas $1269.7 \pm 174.9 ; 40$, inflammatory bowel disease $1210.7 \pm 247.1 ; 34$. The arginase activity differs significantly in the adenoma-carcinoma sequence according to the Duncan's test $(\mathrm{p}<0.05)$.

\section{Introduction}

Tumour markers may provide a valuable tool for the screening and early detection of colorectal neoplasia. Determination of proliferative markers could be used for evaluation of the malignancy risk in 'high-risk' individuals. Activities of enzymes involved in tumour cell differentiation and proliferation were tested for this reason. Ornithine decarboxylase $(1,2)$, urokinasetype plasminogen activator $(3,4)$, cathepsin B $(5,6)$, tyrosine kinase (1), glutathione S-transferase (7), protein kinase $C(8-10)$, sucrase-isomaltase $(11,12)$, alkaline phosphatase (13), lactate dehydrogenase (14) and in the last years also arginase $(15,16)$ activities were reported. In a previous paper we reported a significant correlation of the $\mathrm{M} / \mathrm{H}$ monomer ratio of lactate dehydrogenase in the colonic mucosa with the adenoma-carcinoma sequence (17). The aim of this study was to evaluate arginase activity as a proliferative marker of colorectal mucosa under normal and pathological conditions.

\section{Materials and Methods}

Tissue specimens

Arginase activity was evaluated in a total of 210 patients who underwent endoscopic polypectomy or biopsy at the Department of Medicine, Faculty Clinics, Prague. The following groups were established according to histologic examination: colon cancer $(n=40)$, adenomatous polyps $(n=40)$, inflammatory bowel disease $(n=34)$, post-resection anastomosis $(n=17)$, controls with normal histology $(n=25)$. Fourty-four cases remained nongrouped.

Reproducibility, variations and heterogeneity of arginase determination were studied on 3 cases.

Case A - normal mucosa; 10 biopsies were taken from the distal part of colon; case B - large adenomatous polyp; $43 \mathrm{~mm}$ was cut into 10 parts; case $\mathrm{C}-$ broad sessile polyp; 10 biopsy samples were taken from the lesion.

The proximodistal gradient of arginase activity was studied in the group of 11 patients with segmental biopsies along the large bowel. The following localizations were described: caecum; ascending colon; colon transversum; descending colon; sigmoid; rectum (fig. 1). Only 7 patients with all six tested localizations were used for final evaluation.

\section{Biopsy sample preparation}

Tissue samples of mucosa, polyps or cancers of the large bowel were obtained endoscopically during colonoscopy using the biopsy forceps (Olympus Type FB-24 $U$ ) or as a part of polyps removed by polypectomy. Tissue samples were immediately frozen on dry ice and stored at $-75^{\circ} \mathrm{C}$ (UltraLow BioFreezer, Forma Scientific, USA).

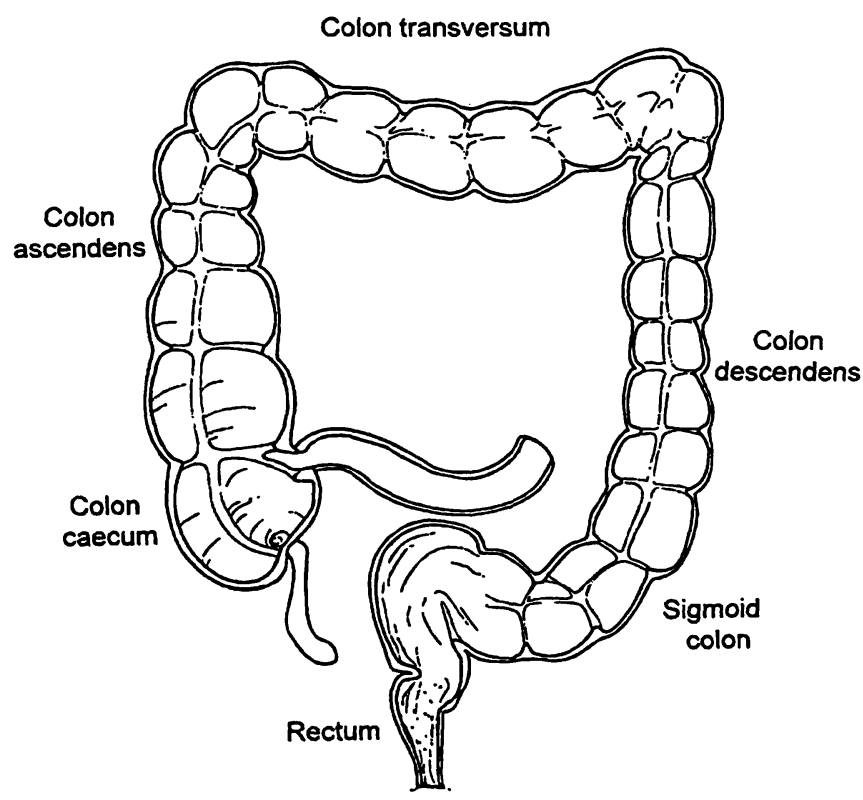

Fig. 1 Graphical scheme of localizations in the large bowel. 
Biopsy samples were homogenized in $5 \mathrm{mmol}$ Tris- $\mathrm{HCl}$ buffer $(\mathrm{pH}$ 7.5) containing $100 \mu \mathrm{mol} / \mathrm{l} \mathrm{MnCl} 2$ by using of a glass-homogenizer for 1 minure in ice-ivater bath. The homogenized material was centrifuged at $18000 \mathrm{~min}^{-1}$ for $60 \mathrm{~min}$ (refrigerated Janetzki K24 centrifuge, $4^{\circ} \mathrm{C}$ ) and the supernatant was used for enzyme activity assay.

\section{Arginase activity assay}

The enzyme activity was determined by our modification of the procedure described by Konarska $(18,19)$. Reagent stock solutions were: $100 \mathrm{mmol} / \mathrm{l}$ arginine (fresh every day). $2 \mathrm{mmol} / \mathrm{l}$ ornithine (stable one month at $4{ }^{\circ} \mathrm{C}$ ), $25 \mathrm{~g} / 1$ ninhydrin (Merck, Germany) in $10 \mathrm{~mol} / 1 \mathrm{acetic} \mathrm{acid} / 2.4 \mathrm{~mol} / 1 \mathrm{phosphoric} \mathrm{acid} \mathrm{(stable} \mathrm{for} \mathrm{several}$ months), $10 \mathrm{mmol} / 1 \mathrm{MnCl}_{2}$ (stable for one month).

The incubation of samples was carried out in a water-bath (Lauda, Germany) at $37^{\circ} \mathrm{C}$ for 120 minutes and stopped by immersing tubes in a boiling water-bath for 5 minutes. The reaction conditions were as follows: $500 \mu \mathrm{l}$ of $35 \mathrm{mmol} / 1$ Tris- $\mathrm{HCl}$ buffer $\mathrm{pH} 9.5-20$ $\mathrm{mmol} / \mathrm{l}$ arginine $-1 \mathrm{mmol} / 1 \mathrm{MnCl}_{2}$ were incubated with $25 \mu \mathrm{l}$ of homogenate and $25 \mu \mathrm{l}$ of $5 \mathrm{mmol} / \mathrm{T}$ Tris- $\mathrm{HCl}$ buffer. The ornithine concentration was determinated by an end-point ninhydrin reaction, carried out in a boiling water bath for 60 minutes. Ninhydrin reagent $(0.5 \mathrm{ml})$ and acetic acid $(1.5 \mathrm{ml})$ were added to the incubation medium. This reaction was stopped by cooling to room-temperature and the colored reaction product was evaluated by using a double-beam spectrophotometer CE 5000 (Cecil, UK) at $515 \mathrm{~nm}$ in a $1 \mathrm{~cm}$ glass cuvette.

Optimal arginine concentration was evaluated from 60 measurements of 5 patients (covering all groups) and arginine concentrations in the range $5-200 \mathrm{mmol} / \mathrm{l}$ (stock solutions) were processed in duplicate.

Ornithine concentration was calculated from calibration standards (0.5-2.0 mmol/l processed with every sample batch. A sample blank was processed without the 120 minute incubation period for each test. Wavelength scan was obtained by using a DU-8B spectrophotometer (Beckman, USA) in the range of 350-750 nm (scan speed $100 \mathrm{~nm} / \mathrm{min}$ ).

Arginase activity was expressed in micromoles of ornithine per minute per gram protein [U/g]. Soluble protein was determined by the Lowry method using bovine albumin as a calibration protein.

\section{Statistical evaluation}

Results were evaluated by the analysis of variance, Student's test and Duncan's test (procedures ANOVA, MANOVA) using the statistical package SPCC PC+ (version 3.1) on a personal computer. With respect to the asymmetric distribution of data, their logarithmic values were used for the determination of Duncan's test.

\section{Results}

\section{Arginase colorimetric method}

Arginase activity in tissue samples was determined by a two-step method. The first enzymatic reaction produces $L$-ornithine from $L$-arginine. The concentration of ornithine is measured by a colorimetric method with ninhydrin. Wavelength scan of the dye produced by the reaction with ninhydrin showed a peak with a maximum at $512 \mathrm{~nm}$ (fig. 2).

The calibration curve in the range $0-2 \mathrm{mmol} / \mathrm{l}$ of ornithine (fig. 3) is linear and the reaction product is not influenced by $\mathrm{MnCl}_{2}$ used for enzyme activation. The vari- ance of $0.37 \%$ was calculated from a total of 60 measurements (10 times of 6 standards).

Optimal arginine concentration was determined for 100 $\mathrm{mmol} / \mathrm{l}$ stock solution. The sigmoid curve was found in the range of 5-100 mmol/l arginine (fig. 4). A significant decrease of activity was found in all samples for $200 \mathrm{mmol} / \mathrm{l}$ arginine concentration. This may be due to increasing concentration of the reaction products.

\section{Reproducibility and variations of arginase}

The determination of arginase activity in colonic tissue may be affected mainly by cell heterogeneity and sample processing. Three different types of sample were

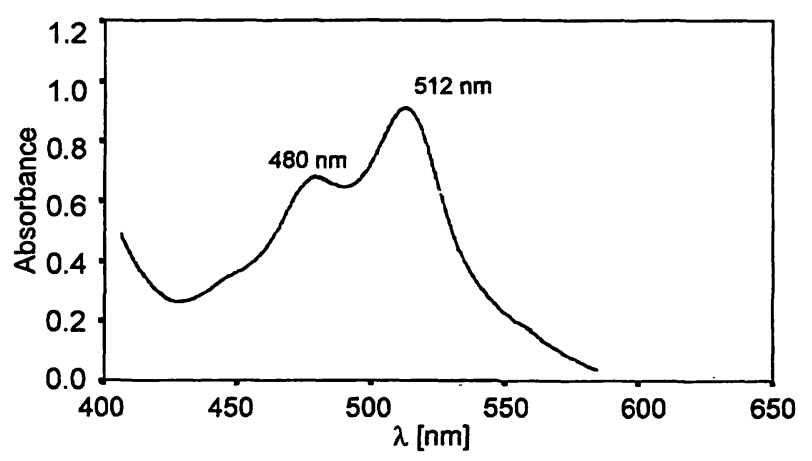

Fig. 2 Wavelength scan of coloured ninhydrin reaction product in the range of $400-650 \mathrm{~nm}$.

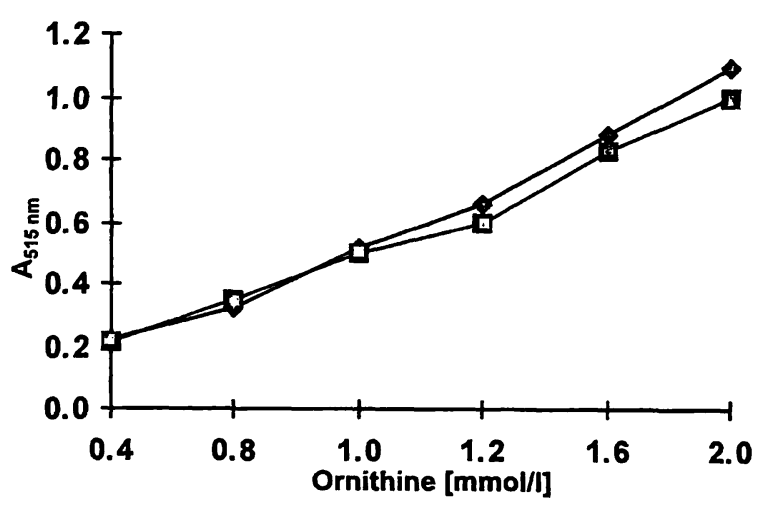

Fig. 3 Calibration curve of the ornithine assay in presence - $\mathrm{a}-$ or absence -- of $\mathrm{MnCl}_{2}$ in concentration range $0-2.5 \mathrm{mmol} / \mathrm{l}$.

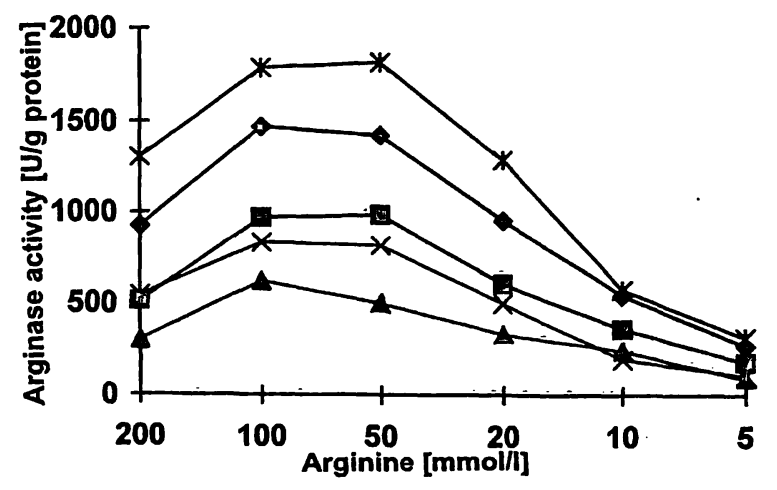

Fig. 4 Arginase activity in U/g protein determined in 5 subjects [P. B. * , V.T. $\diamond$, M. R. घ, B.S. $\times$, J. V. $\Delta$ ] at different arginine concentration; $5-200 \mathrm{mmol} / \mathrm{l}$ of the stock reagent. 
tested for variations [reproducibility] of arginase activity. In case A (10 samples of normal mucosa obtained by biopsy) mean activity $\pm S E 73.00 \mathrm{U} / \mathrm{g} \pm 4.60$; range $55-98$, in case $B$ (10 slices of a large adenoma) the corresponding values were $208.00 \pm 17.46$; range $157-336$, and in case $C$ (10 samples of large sessile adenoma) $254.50 \pm 25.99$; range $150-383$. The distribution of values around the mean (variance) was found to be 14.3 times higher for case $B$ and 31.7 times higher in case $\mathrm{C}$ compared to case A (normal mucosa).

Within-run precision of the arginase assay was evaluated on 50 doublets of tissue homogenate covering the absorbance range $0-1.8$. Standard deviations of absorbance were found in the range $0-0.07$, corresponding to arginase activity $0-98 \mathrm{kU} / \mathrm{l}$.

The range of normal values of arginase in the colonic mucosa, 33.1-173.7 U/g, was calculated from values of the control group in logarithmic transformation as mean $\pm 2 \mathrm{SD}$.

\section{Proximodistal gradient of enzyme activity}

Arginase activity was determined in 58 mucosal biopsy samples taken along the large bowel of 11 patients. Individual values in the range of $20-180 \mathrm{U} / \mathrm{g}$ protein were plotted for each case against colon localizations (fig. 5). Four cases with only 4 biopsies (not complete gradient) were omitted for final evaluation. There were no significant changes along the colon, confirming absence of a proximodistal gradient of arginase activity in the human large bowel.

\section{Clinical significance of arginase activity}

The arginase activity (mean \pm SE) in five groups (fig. 6) - colorectal cancer, adenomatous polyps, inflammatory bowel disease, postresection anastomosis and controls were $1269.7 \pm 174.9,199.4 \pm 19.2,1210.7 \pm 247.1$, $217.9 \pm 110.0$, and $83.2 \pm 7.3 \mathrm{U} / \mathrm{g}$ of protein, respectively. The statistical analysis of variances [Duncan's test] displayed significant difference between the group of normal mucosa and all pathological groups $(p<0.05)$ as well as between the groups of colorectal cancer and inflammatory bowel disease and the groups with adenomas and mucosa of the postresection anastomosis $(p<0.05)$.

\section{Discussion}

Cancer development represents a very complex process involving different stages defined by biochemical and histopathological events (20). Several biochemical tumour markers (21) have been tested to support tumour differential diagnosis, follow-up and early cancer detection. Proteinases, like cathepsin B, D or plasmino- gen activator, have been proposed to participate in the metastatic cascade. Ornithine decarboxylase, one of the rate-limiting enzymes in the polyamine pathway, polyamines themselves (putrescine, spermidine, spermine and cadaverine) have an essential role in cell proliferation (22). Immunochemical and immunohistochemical methods are used to prognosticate the risk of cancer reccurence $(23,24)$. The common main goal of all of these techniques and methods is to distinguish between normal, proliferating and carcinomatous mucosa.

Arginase ( $L$-arginine amidinohydrolase, EC 3.5.3.1) converts $L$-arginine into $L$-ornithine and urea. The elevated activity of arginase has been reported in serum as well as in tissues in colorectal $(16,25,26)$, gastric (15) and mammary (27) carcinomas. The ELISA assay was developed to evaluate arginase plasma levels (28). This study was designed to investigate methodological aspects of arginase activity determination in the biopsy sample tissue of colonic mucosa.

Arginase activity in the colonic mucosa is determined by a two-step method according to Konarska $(18,19)$. The concentration of ornithine (as a product of the first reaction) is measured by a colorimetric method

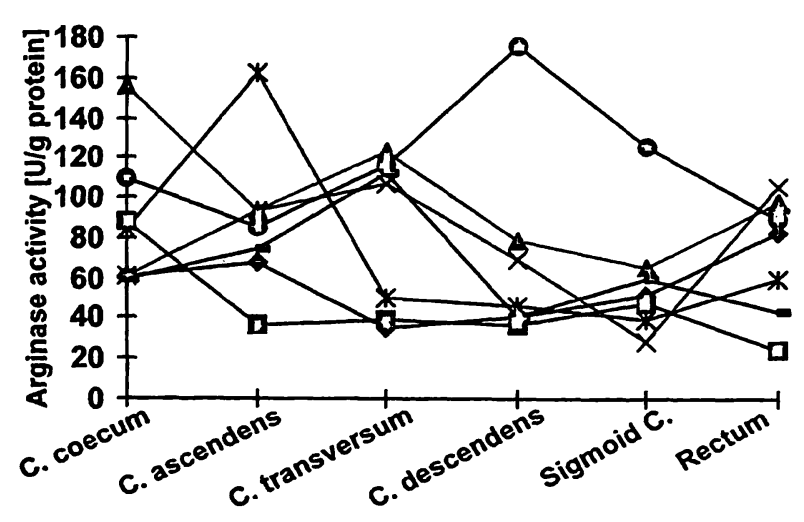

Fig. 5 Arginase activity in U/g protein determined in 7 subjects [L.H. X, V.O. $\Delta$, H.J. ๑, J.S. $\diamond$, J.S. *, J.K. ロ, J.K. $\square]$ at different localizations in the proximodistal gradient.

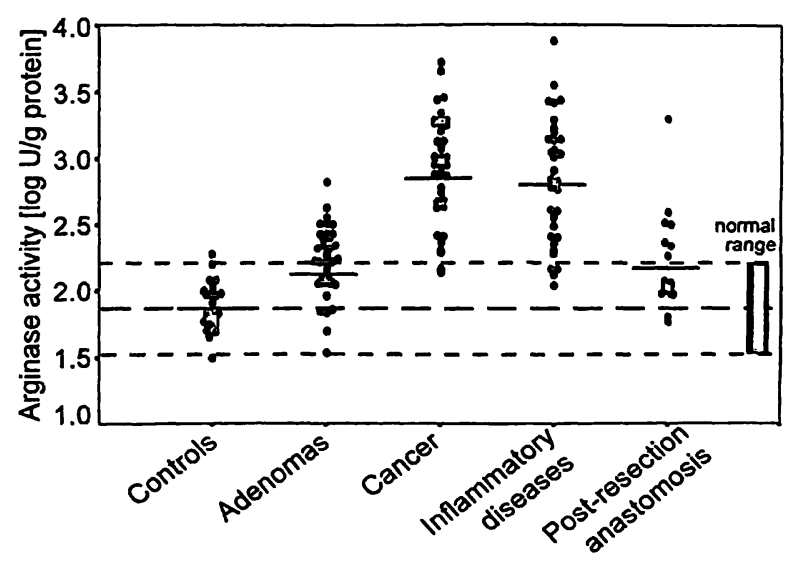

Fig. 6 Arginase activity in U/g protein (logarithmic scale) determined in control group $(n=16)$, adenomas $(n=38)$, colorectal cancer $(n=39)$, inflammatory diseases $(n=27)$ and post-resection anastomosis $(n=16)$. 
with ninhydrin. We confirmed conditions for the colorimetric assay by wavelength scan of the end-product and linearity of the calibration curve. Manganese chloride used to activate the enzymatic activity $(29,30)$ did not affect the assay linearity. Variations of the ornithine concentration measurement were found to be less than $1 \%$.

We found no differences in arginase activity along the large bowel, i. e. there is no proximodistal gradient of this enzyme in the colonic mucosa. The reproducibility of the arginase assay in the mucosal samples is considerably influenced by the cell heterogeneity of the tissue sample. In the normal mucosa the variation amounted to $\pm 19.9 \%$ of the mean activity, in adenomatous polyps this variation was much higher due to higher cell heterogeneity.

\section{References}

1. Arlow FL, Colarian J, Calzada R, Luk GD, Majumdar APN. Differential activation of ornithine decarboxylase and tyrosine kinase in the rectal mucosa of patients with hyperplastic and adenomatous polyps. Gastroenterology 1991; 100:1528-32.

2. Desai TK. Parikh N, Bronstein JC, Luk GD, Bull AW. Failure of rectal ornithine decarboxylase to identify adenomatous polyp status. Gastroenterology 1992; 103:1562-7.

3. Mulcahy HE, Duffy MJ, Gibbons D, McCarthy P, Parfrey NA, O'Donoghue DP, et al. Urokinase-type plasminogen activator and outcome in Duke's B colorectal cancer. Lancet 1994; 344:583-4.

4. Konno H, Tanaka T, Marou Y, Nishino N, Nakamura S, Baba $S$, et al. Correlation between tumor proliferation and tumor tissue level of urokinase-type plasminogen activator. Eur Surg Res 1993; 25:239-44.

5. Campo E, Munoz J, Miquel R, Palacin A, Cardesa A, Sloane $\mathrm{BF}$, et al. Cathepsin B expression in colorectal carcinomas correlates with tumor progression and shortened patient survival. Am J Pathol 1994; 145:301-9.

6. Leto G, Tumminello FM, Russo A, Pizzolanti G, Bazan V, Gabbia N. Cathepsin D activity levels in colorectal cancer: correlation with cathepsin B and $\mathrm{L}$ and other biological and clinical parameters. Int J Oncol 1994; 5:509-15.

7. Peters WHM, Nagengast FM, Wobbes T. Glutathione S-transferases in normal and cancerous human colon tissue. Carcinogenesis 1989; 61:35-9.

8. Mcgarrity TJ, Pfeiffer LP. Protein kinase-C activity as a potential marker for colorectal neoplasia. Dig Dis Sci 1994; $39: 458-63$

9. Pongracz J, Clark P, Neoptolemos JP, Lord JM. Expression of protein kinase $C$ isoenzymes in colorectal cancer tissue and their differential activation by different bile acids. Int $\mathrm{J}$ Cancer 1995; 61:35-9.

10. Sakanoue $Y$, Hatada $T$, Kusunoki $M$, Yanagi $H$, Yamamura $T$, Utsunomiya J. Protein kinase-C activity as marker for colorectal cancer. Int J Cancer 1990; 48:803-6.

11. Wiltz O, Ohara CJ, Steele GD, Mercurio AM. Sucrase-isomaltase-A marker associated with the progression of adenomatous polyps to adenocarcinomas. Surgery 1990; 108:269-76.

12. Beaulieu JF, Weiser MM, Herrera L, Quaroni A. Detection and characterization of sucrase-isomaltase in adult human colon and in colonic polyps. Gastroenterology 1990; 98:1467-77.

13. Wei JS, Chung NC, Wei LLL, Tzeng WF, Liu TZ, Wang JY. High-molecular-mass alkaline phosphatase as a tumor marker for colorectal cancer - comparison of 2 test methods. Clin Chem 1993; 39:540-3.
High arginase activity was found in the group of colorectal cancer and inflammatory bowel disease. This corresponds well with the endeavor to use arginase as a proliferative marker for colonic mucosa. The significant differences were found between normal and pathologically changed mucosa, and between tissue with higher proliferation (cancer and inflammatory disease) and adenomatous polyps or post-resection mucosa in the large bowel anastomosis. Further studies are aimed at the diagnostic efficiency of arginase activity of the colonic mucosa and at the distribution of this activity in mucosa surrounding neoplastic lesions.

\section{Acknowledgements}

This study was supported by the Internal Grant Agency of the Czech Ministry of Health No. 2303-3/94.

14. Maté J, Duran R, Lara S, Pajares JM, Moreno-Otero R. A study of the lactic dehydrogenase isoenzyme patterns in the adenoma-carcinoma sequence of the colon. Hepato-Gastroenterology $1993 ; 40: 471-4$.

15. Wu CW, Chi CW, Lin EC, Lui WY, P'Eng FK, Wang SR. Serum arginase level in patients with gastric cancer. J Clin Gastroenterol 1994; 18:84-5.

16. Leu SY, Wang SR. Clinical significance of arginase in colorectal cancer. Cancer 1992; 70:733-6.

17. Kocna P, Frič P, Slabý J. Heterogenity of lactate-dehydrogenase, alkaline phosphatase and creatine-kinase in the colon mucosa (in Czech). Biochem Clin Bohemoslov 1991; 20:133-42

18. Konarska L, Tomaszweski L. A simple quantitative micromethod of arginase assay in blood spots dried on filter paper. Clin Chim Acta 1986; 154:7-18.

19. Konarska L, Tomaszewski L. Studies of the small intestine. I. Topographical distribution and some properties of the small intestine L-arginase in the rat. Biochem Med 1975; 14:25062.

20. Zusman I. Variability of neoplastic parameters in colon tumours, and its significance in diagnostic practice. Biol Philos Soc 1995; 70:107-60.

21. Schwartz MK. Enzymes used in predicting high risk to colon cancer. Clin Biochem 1990; 23:395-8.

22. Porter CW, Herrera-Ornelas L, Pera P, Petrelli NF, Mittelman A. Polyamine biosynthetic activity in normal and neoplastic human colorectal tissues. Cancer 1987; 60:1275-81.

23. Dileo A, Messa C, Misciagna G, Guerra V, Taveri R, Leo S. Prognostic value of cytosolic estrogen receptors in human colorectal carcinoma and surrounding mucosa - preliminary results. Dig Dis Sci 1994; 39:2038-42.

24. Higuchi CM, Wang WQ. Comodulation of cellular polyamines and proliferation: biomarker application to colorectal mucosa. J Cell Biochem 1995; 57:256-61.

25. Frič $P$, Zavoral $M$, Kocna $P$, Pelech $T$, Benešová $A$, Zádorová $Z$, et al. Arginase activity of normal and diseased colorectal mucosa. In: Faivre J, editor. European group for colorectal cancer screening. Proceedings of the Annual Meeting of the European Group for Colorectal Cancer Screening; 1993 Aug 26-28; Dijon (France). Smith Kline Diagnostics 1993:50-2.

26. Kocna P, Frič P, Zavoral M, Benešová A, Pelech T. Arginase - new marker of mucosal proliferating activity in the screening for colorectal neoplasia. Clin Biochem Rev 1993. 14:237.

27. Štraus B, Čepelak I, Festa G. Arginase, a new marker of mammary carcinoma. Clin Chim Acta 1992; 210:5-12. 
28. Wang SR, Chen ML, Huang MH, Lin HY, Tsai JJ, Kuo BIT. Plasma arginase concentration measured by an enzyme-linked immunosorbent assay (ELISA) in normal adult population. Clin Biochem 1993; 26:455-60.

29. Maggini S, Stoecklin-Tschan FB, Morikofer-Zwez S, Walter P. New kinetic parameters for rat liver arginase measured at nearphysiological steady-state concentrations of arginine and $\mathrm{Mn}^{2+}$. Biochem J 1992; 283:653-60.
30. Zamecka E, Porembska Z. Five forms of arginase in human tissues. Biochem Med Metab Biol 1988; 39:258-66.

Received November 15, 1995/April 9, 1996

Corresponding author: MUDr. Petr Kocna CSc., Laboratory of Gastroenterology, 1st Medical Faculty UK, Karlovo náměstí 32, CZ-121-11 Praha-2, Czech Republic 


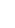

